\title{
Inundation scenarios for flood damage evaluation in polder areas
}

\author{
L. M. Bouwer ${ }^{1}$, P. Bubeck ${ }^{1}$, A. J. Wagtendonk ${ }^{2}$, and J. C. J. H. Aerts ${ }^{1}$ \\ ${ }^{1}$ Institute for Environmental Studies, Faculty of Earth and Life Sciences, Vrije Universiteit, Amsterdam, The Netherlands \\ ${ }^{2}$ Spatial Information Laboratory, Vrije Universiteit, Amsterdam, The Netherlands
}

Received: 2 April 2009 - Revised: 3 November 2009 - Accepted: 15 November 2009 - Published: 3 December 2009

\begin{abstract}
We present an approach for flood damage simulations through the creation of a comparatively large number of inundation scenarios for a polder area, using a highresolution digital elevation model. In particular, the method could be used for detailed scenario studies of the impact of future socioeconomic and climatic developments on flood risks. The approach is applied to a case-study area in the south of the Netherlands along the river Meuse. The advantage of our approach is that a large number of potential flood events can be created relatively fast without hydrodynamical calculations, and that it can be applied to high-resolution elevation models and for large areas. The large number of flood scenarios and the high horizontal resolution reduces at least part of the uncertainties encountered in flood loss modelling. The approach with a low horizontal-resolution (100-m) for loss modelling results in an overestimation of losses by up to $22 \%$ for high density urban areas, and underestimation of $100 \%$ for infrastructure, compared to the high-resolution $(25-\mathrm{m})$. Loss modelling at $5-\mathrm{m}$ horizontal resolution shows that aggregate losses may be overestimated by some $4.3 \%$, compared to the $25-\mathrm{m}$ resolution. The generation of a large variety of inundation scenarios provides a basis for constructing loss probability curves. The calculated range and expected values of damages compare reasonably well with earlier independent estimates.
\end{abstract}

\section{Introduction}

Flat polder areas protected by dikes exist in many places around the globe, especially in low-lying river deltas. These areas are particularly vulnerable in the event of dike breaches during high water levels and because of high concentrations of people and capital (Smith and Ward, 1998). For decisions and investments in flood risk management reliable estimates of potential damages are needed (e.g. Vrijling et al., 1998).

Correspondence to: L. M. Bouwer (laurens.bouwer@ivm.vu.nl)
Because of the low probability nature of extreme floods and therefore the limited availability, or even complete absence, of historical loss data, simulation of loss events using catastrophe models is needed in order to arrive at a realistic range of potential damages. This is particularly the case in the Netherlands, where flood events due to dike breaches with extensive impacts are very rare. Loss events that have been well documented only comprise a major storm surge event in 1953 (Van Dantzig, 1956; Gerritsen, 2005). More recently, river flood events in 1993 and 1995 involved considerable economic losses, but were limited to relatively smallscale inundations and no dike breaches occurred (Wind et al., 1999). By applying modelling approaches that use lossinundation relationships based on flood events in other regions of the world, it is possible to estimate potential flood risks for extreme flood events.

While river basins in valleys mainly face different inundation levels during flooding, low lying polder areas face a multitude of flood events that can take place in different locations, with very different consequences. The location of flooding in polders depends on the unpredictable failure of flood defences, which poses a particular problem for the accurate assessment of potential flood risks. This is usually solved by the creation of different flood scenarios. In particular maximum inundation depths from flood scenarios are used to calculate damages (Messner et al., 2007; Rijkswaterstaat, 2005a). Two-dimensional hydrodynamic modelling has commonly been used to create estimates of possible flood extents and inundation depths for specific floods (Van der Most and Wehrung, 2005; Rijkswaterstaat, 2006; Jonkman et al., 2008). However, the relatively small number of scenarios that can be reasonably produced in this manner, and the relatively coarse horizontal resolution of the flood scenarios limit the usefulness of these models for high spatial resolution loss estimates for large areas. There is usually a trade-off between the physical detail of the model, and the spatial scale and size of the study area (Hunter et al., 2007). Particularly, the construction of loss probability curves requires a large set of potential damage estimates (Messner et al., 2007). Such

Published by Copernicus Publications on behalf of the European Geosciences Union. 
loss probability curves are needed, since they provide important information for decision-making on flood risk management policies, as they can show the range of possible losses. Loss probability curves allow the evaluation of the integral of the loss curve, including extreme values. Assessments based on probabilistic risk estimates can help to support decisions on the allocation of public finances for risk reduction, the appraisal of flood management projects, and to demonstrate the appropriateness of spending of public budgets (Vrijling, 2001; MNP, 2004; Messner et al., 2007; De Bruijn and Klijn, 2009). Additionally, the potential introduction of private insurance in the Netherlands for flood losses due to dike breaches requires accurate evaluation of losses and their probabilities (Botzen and Van den Bergh, 2008).

The relatively small number of flooding scenarios currently available from hydrodynamic modelling in the Netherlands may not sufficiently allow to take into account the variation in quantities of inundating water, the uncertainties associated with the potential failure of secondary flood defences, and the different potential locations of dike breaches and associated losses. Additionally, the spatial resolution of inundation scenarios determines to a large extent the accuracy of estimates made using depth-damage functions, and therefore the accuracy of potential losses. Hydrodynamic modelling, depending on type of model involved, is typically limited to a coarse resolution, or a limited area of investigation, due to high computational power demand and time. Current estimates of flood risk in the Netherlands are typically constrained to 100-m resolution. For a large study area, the estimated inundation level relative to the actual ground level elevation (vertical accuracy), and exact location of the boundaries of different loss categories (horizontal accuracy) are only roughly approximated, leading to uncertainty in the estimation of potential losses. Obviously, an infinitely fine resolution would be ideal, but there is a limit to any analysis. Here we demonstrate the usefulness of a considerable increase in inundation resolution, by using an elevation model at 5-m horizontal resolution. The Dutch project "Flood risks and safety in the Netherlands" (Floris) is to provide benchmark estimates for flood risks on which national policies will be based that are related to evacuation, flood protection, and risk reduction (Rijkswaterstaat, 2005b; Van der Most and Wehrung, 2005). The project provides a detailed flood risk analysis for the case study area, using scenarios from hydrodynamic modelling on a 100-m resolution. This set of flooding scenarios however comprises only 13 scenarios at present (Rijkswaterstaat, 2006).

We present an alternative approach for creating a larger number of flood scenarios in an area protected by one main dike, using a high-resolution digital elevation model. This number of scenarios is larger compared to the current hydrodynamic scenarios that are available. Our approach in many cases will be easier and quicker carried out for a more extensive study area. It compliments more detailed hydrodynamic approaches, by providing a risk assessment with sufficient accuracy, but at a larger geographic scale. It also compliments the first approximate national scale risk assessments that have recently been made of current and future flood risks (e.g. MNP, 2004; Rijkswaterstaat, 2005a; Klijn et al. 2007; Aerts et al., 2008), but that do not consider the various different flood events that could occur in individual polders.

Our method is mostly aimed at providing a platform for giving more detail to dynamic estimates of risk over time, due to land-use change and climate change. The approach is applied to a study area along the river Meuse in the south of the Netherlands. Potential losses are then calculated with a simple loss model using depth-damage curves. The approach involves the identification of 23 individual sub-basins that can potentially be submerged and consequently the creation of flood scenarios consisting of different combinations of flooded sub-basins. The damage module that we apply can incorporate a small set of parameters that describe current and future land-use, as well as the fraction of losses based on estimated inundation depths. Subsequent research will apply a range of land-use and climate change scenarios in order to estimate the impact of socioeconomic and climatic changes on potential future flood losses. In an accompanying paper (Bouwer et al., 2009), we provide a scenario analysis for the year 2040, based on the scenario and loss modelling approach presented here. Such projections of future risk are useful for the estimation of low probability events that could occur over the next tens of years, and that determine the benefit of investment decisions over these timescales. Such assessments require methods that are sufficiently detailed but simple and feasible to carry out (Klijn et al., 2007; Aerts et al., 2008).

Our approach assumes that individual basins within the main dike ring area are filled up to the level of the lowest basin boundary. The approach ignores the fact that floods have a dynamic nature and assumes only losses from inundation. This is an acceptable simplification, considering the relatively flat topography of polder areas, and the fact that high flow velocities generally occur only locally, close to the dike breach. The method mimics approaches applied for valley flooding that use linear interpolation of flood water levels and their intersection with models of surface elevation (Apel et al., 2009). Although these methods perform less well then more detailed hydrodynamic modelling, the choice of flood loss model generally is of more concern then the hazard model (Apel et al., 2009). The main advantage of our approach is that a large range of potential flood events can be created with relatively little effort. For our case study area we apply an elevation model with 5-m horizontal resolution. Both the large range of the flood scenarios and the high horizontal resolution would reduce at least part of the uncertainties encountered in flood loss modelling. The estimated flood losses resulting from our approach are compared to the loss estimates from the Floris project (Rijkswaterstaat, 2006). 


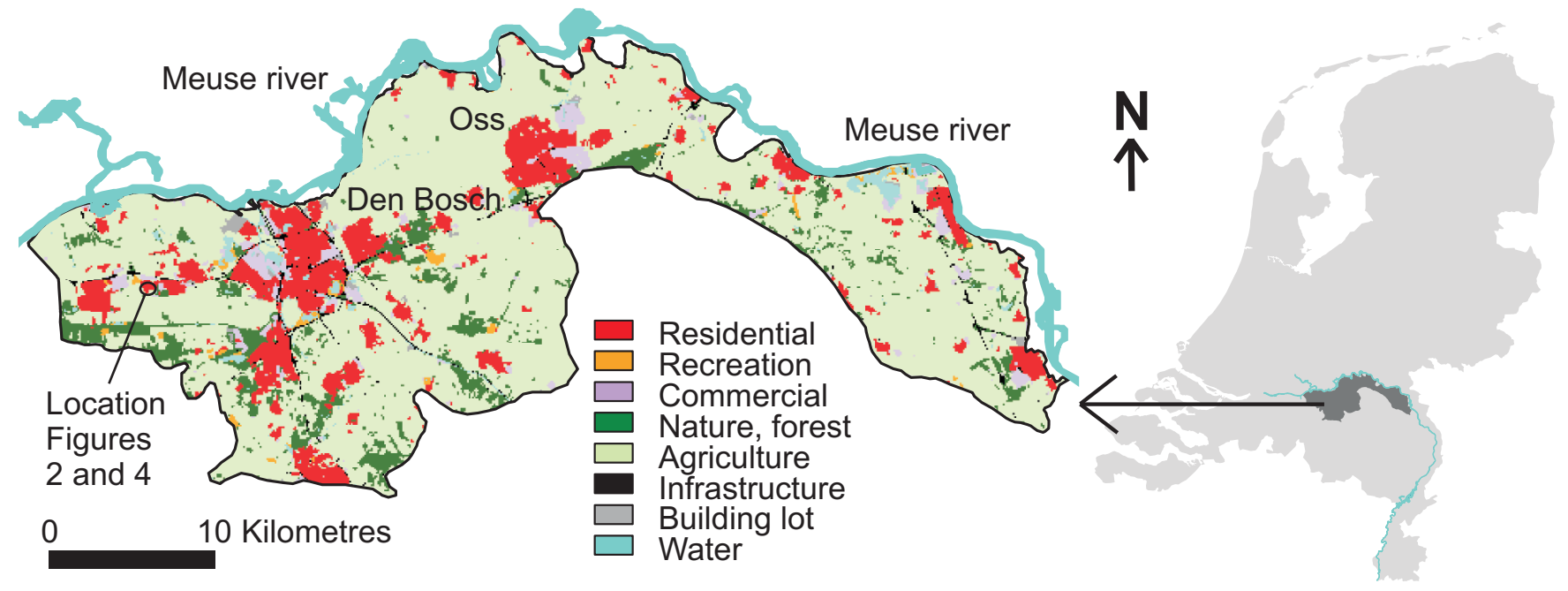

Fig. 1. Land-use map of the study area, dike ring area 36 Land van Heusen/de Maaskant (source: Land-use Scanner).

\section{Study area, methods and data}

The study area comprises dike ring area 36, called Land van Heusden/de Maaskant in the south of the Netherlands (Fig. 1). A dike ring area is an area enclosed by a single primary flood defence (dikes), and in some areas also by higher grounds. Dike ring area 36 consists of a polder area of $740 \mathrm{~km}^{2}$, and is bounded by the river Meuse to the north and east, and is protected by dikes along these stretches. The flooding hazard in the area consist of high river discharges on the river Meuse, that mainly occur in winter time, and that can lead to high water levels and consequent failure of stretches of dikes. Approximately $79 \%$ of the area is occupied by agriculture, nature, and recreation, and another $20 \%$ by urban areas. The major cities located in this area are Den Bosch (136000 inhabitants) and Oss (76000 inhabitants). Some major infrastructure features such as highways, roads, dikes and canals dissect the area.

The study area is relevant for studying flood risks for two reasons. First, it is representative for The Netherlands, as it comprises both high density urban areas, in particular the cities of Den Bosch and Oss, and extensive agricultural areas, in particular grassland. Secondly, it has been found that the area, in contrast to some smaller dike ring areas, is unlikely to flood completely in the event of a dike breach (Rijkswaterstaat, 2005a: p. 24). Therefore, modelling approaches are needed that take into account the various possible inundation events that affect different parts of the study area and that could occur in the event of dike failures. All areas in the Netherlands protected by dikes have been assigned different protection levels under the Flood Defence Act of 1996, according to the potential severity of flooding and the number of people and amount of capital at risk (Van der Most and Wehrung, 2005; Bouwer and Vellinga, 2007). According to this Act, our case study area is to be protected by dikes that can withstand a river water level with a recurrence interval of 1250 years. Note that this recurrence interval is different from flooding probabilities for the dike ring area, as a dike failure in one place would not lead to immediate flooding of the entire area. Moreover, dike failure can also occur at water levels with a frequency higher than once in 1250 years (Vrijling, 2001). Actual failure probabilities of individual stretches of dikes and other elements of the flood protection system have been calculated for this dike ring and other parts of the Netherlands by the Floris project (Rijkswaterstaat, 2005c).

\subsection{Surface elevation data}

A high-resolution elevation model is available from the Ministry of Transport, Public Works and Water Management for the Netherlands, called the "Actueel Hoogtebestand Nederland" (AHN; Current Elevation database Netherlands). Point measurements for this model have been derived using airborne laser altimetry at an original point density of 1 measurement per $16 \mathrm{~m}^{2}$ (Huising and Pereira, 1998). A number of different raster products were made from these measurements, one of which is a gridded elevation model at a horizontal resolution of $5 \mathrm{~m}$, which was created using inverse distance weighting interpolation. The vertical accuracy of the elevation data is estimated to be some $10-15 \mathrm{~cm}$ for flat terrain (Huising and Pereira, 1998). The companies that collected the data filtered this grid for heights resulting from buildings and vegetation in non-urban areas. However, the grid still contains heights distorted by buildings and vegetation in the urban areas, and also contains some "nodata" gaps, in particular over water areas. Slight differences in elevation can result in considerable inaccuracies in the estimation of potential damages using depth-damage curves. 
Especially in urban areas it is essential to filter out values that do not reflect the ground level, as urban areas usually account for the largest share of damages (e.g. Rijkswaterstaat, 2006).

For the assessment of inundation depths to which buildings and other valuable objects are exposed, it thus is crucial to have an accurate estimate of the actual (vertical) surface elevation, as well as actual (horizontal) location of these inundation depths as they relate to the actual location of people and capital at risk. This can be achieved by a high-resolution elevation model. The surface level is what is usually referred to as the 'bare earth'; i.e. the surface free from vegetation, buildings and other man-made structures (NRC, 2007). In order to derive this bare earth elevation, a correction is needed for high features such as trees and houses in urban areas. We applied a minimum filter to the 5-m grid which moves a rectangular search window over the grid and assigns the lowest value found in every search window to the centre cell.

Because of the different sizes of the objects in these areas, three different filters were applied for industrial, residential and rural areas. The three categories were defined on the basis of CBS land-use statistics data (CBS, 2000). For industrial areas, where the elevation of relatively large building complexes needs to be corrected, a large search window of 18 grid cells wide (equal to $8100 \mathrm{~m}^{2}$ ) was chosen. For residential areas a smaller search window of 10 grid cells wide (equal to $2500 \mathrm{~m}^{2}$ ) was chosen, as most residential buildings are smaller and occupy less space than buildings in industrial areas. For rural areas, where only minor distortions need to be corrected, a search window of only two grid cells wide (equal to $100 \mathrm{~m}^{2}$ ) was applied. Within this area it is assumed that the lowest cell value represents the actual local elevation. Some man-made structures, in particular impermeable sediment bodies that carry roads, railway-lines, dikes and other infrastructure features were exempted from the minimum filter, as they form important secondary barriers to flooding. They therefore have maintained their original elevation. Within the Floris project, minimum filters have been applied as well to produce elevation data for the flood risk estimates (Rijkswaterstaat, 2005a). The advantage of the applied procedure for the correction of elevation values is that it does not require extensive secondary information sources, for example datasets that describe the exact location of buildings. Additionally, the method is capable of correcting other high features, and filling most of the "no-data" gaps in the raster, which occur mainly over water areas. Note that the reconstruction of actual elevation over water surfaces is not important for our purpose, as no flood damages are calculated for areas occupied by water.

A visual assessment of a part of the corrected elevation model (Fig. 2b) and a comparison with an aerial photograph (Fig. 2c) shows that the filtering technique is successful in removing elevations resulting from buildings, trees and other high structures from urban areas, while leaving intact the relative higher elevation of old city centres. Waterways and ditches, however, are slightly widened.
In addition to the visual inspection, we performed a validation of the vertical elevation values, by comparing the grid elevation to the surface elevation as measured on the ground by topographical surveys. These data were collected during the 1950s and 1960s, and are part of the TOP10 vector dataset for the Netherlands. Field measurements are no longer made, as the AHN dataset has superseded the TOP10 elevations. For the case-study area depicted in Fig. 2, a total of 216 individual point measurements from the year 1954 were collected from this dataset (Fig 2d), and compared against the corrected and uncorrected DEM on the basis of the AHN data. The comparison of data was split for urban and industrial areas on the one hand, and rural areas on the other (Fig. 2d), in order to attribute offsets to land-use type. What is clear is that the greatest offset in the uncorrected DEM occurs for urban and industrial areas (Fig. 3a), which is about $+52 \%$ on average. After correction, the average difference is only $7.4 \%$. And except for a few outliers, which concern high elevations on a dike in a rural area, where trees result in large deviations of the DEM, the elevation for the urban and industrial areas that comprise the largest loss categories approaches the actual measured elevations very well (Fig. 3b). For rural areas, the correction leads to a slight reduction in the deviation between the AHN data and the field measurements $(3.0 \%$ and $0.3 \%$ difference, respectively for the uncorrected and corrected DEM).

It should be noted, however, that this analysis captures only part of the effect of the filtering technique. Only a few point measurements coincide with grid cells of the DEM that reflect the height of houses. Thus, effect of correction is shown only for these few locations. In fact, a much larger number of grid cells representing building heights is corrected by applying the filter technique. We therefore also include a comparison between the difference of the original elevation model and the filtered elevation model with the actual location of houses (Fig. 4a). The effect of the filtering in urban areas shows again that high obstacles (including vegetation and vehicles between the buildings) are accurately removed. The location of buildings was taken from the TOP10 vector dataset for the Netherlands. The aerial photo in Fig. $4 \mathrm{~b}$ provides further evidence that the disturbance from buildings and other objects has been removed from the elevation data.

\subsection{Development of inundation scenarios}

Several hydrological factors affect the extent of damage, including inundation depth, flow velocity, the duration of inundation, and pollution. However, inundation depth is usually the main parameter from which the fraction of damages is calculated (Messner et al., 2007). Generally, damage due to high flow velocities only occurs in a small area near the dike breach. This especially holds true for polder areas, due to their flat topography, causing flow velocities to be relatively low in most areas. Moreover, research has found 
a)

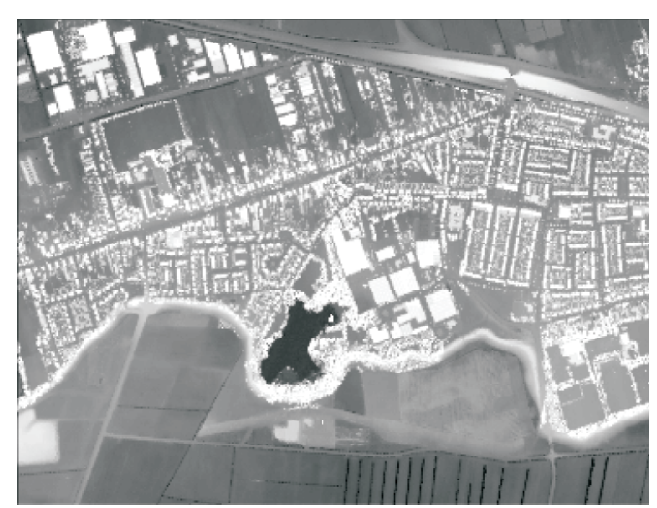

c)

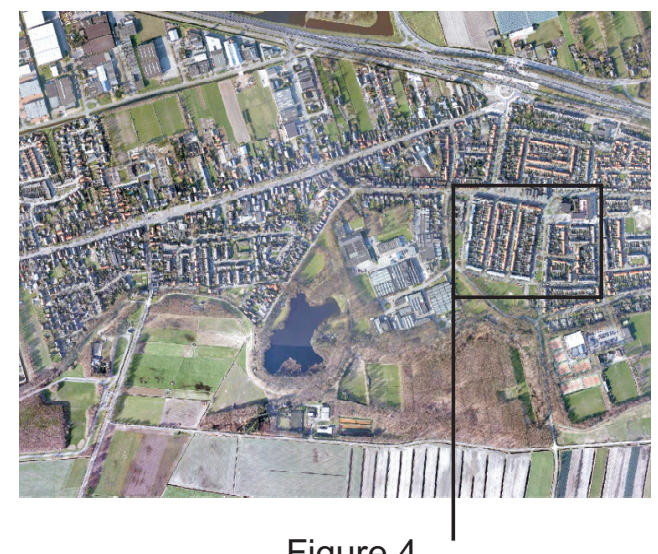

b)

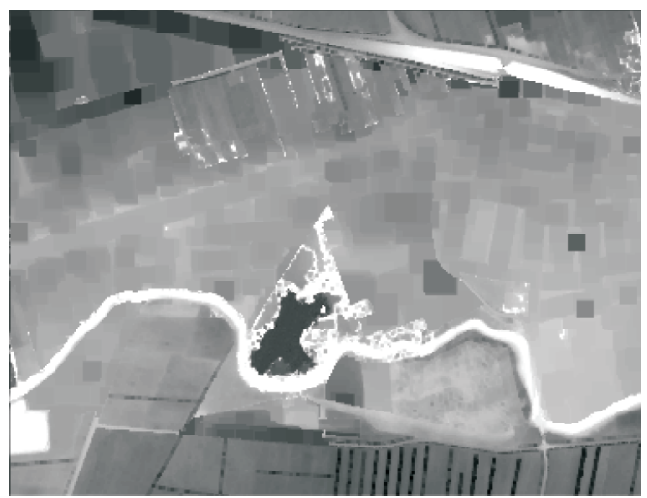

d)

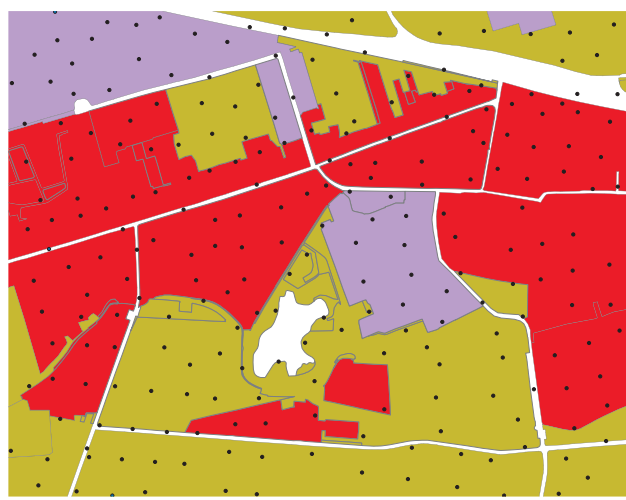

Elevation [m]

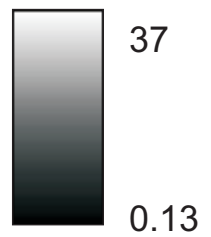

Figure 4

\section{0 metres}

Fig. 2. Original 5-m elevation model (a) and after minimum filter application (b), aerial photograph of the same area in the year 2007 (c), and point ground level field measurements and land-cover classes (d), for location see Fig. 1.

that high flow velocity has a considerable influence on damages to roads, but is of minor importance for other loss categories (Kreibich et al., 2009). In the present study therefore the main interest is to determine what maximum inundation depth can occur in different segments of the polder in the study area. The inundation estimate can thus be reduced to a static situation of maximum inundation over an area, as opposed to a dynamic approach that attempts to simulate actual flow of water and inundation depths for different locations over time. The impact of high flow velocities is therefore ignored in this study.

The topography of a polder area that is delineated by a single dike is not completely flat however, and can be subdivided into a number of individual "drainage" areas. Using a Geographic Information System (GIS) these basins were identified in an automated fashion (ESRI, 2009). This analysis is the basis for delineating the individual basins. The minimum size of the basins is determined by the main linear obstacles that can be recognized in the case study area. The basins are of sufficient size to accommodate large volumes of water, as we show later. Using the automated approach, a total of 23 sub-basins were found to describe the major
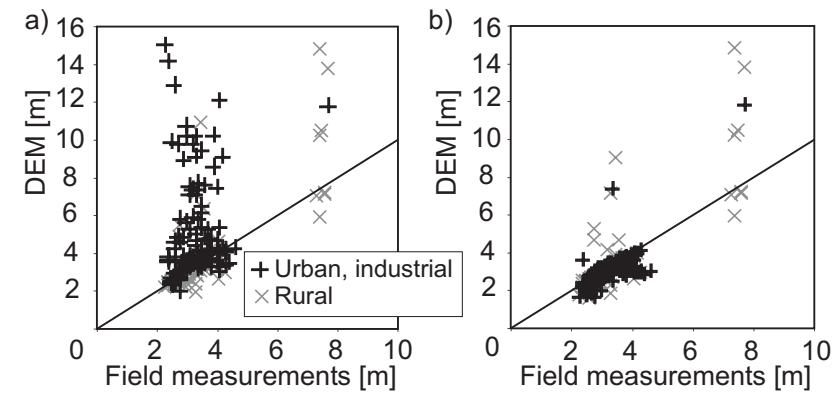

Fig. 3. Comparison of digital elevation model (DEM) values with elevation field measurements for the uncorrected (a) and corrected DEM (b).

individual compartments that are present in the elevation model for the area, recognizing the importance of major boundaries created by dikes and other sediment bodies that carry main infrastructure, such as roads and railway lines (Fig. 5). By combining different sets of basins, we arrive at 42 different inundation scenarios that span both very small and large inundation events. 
a)

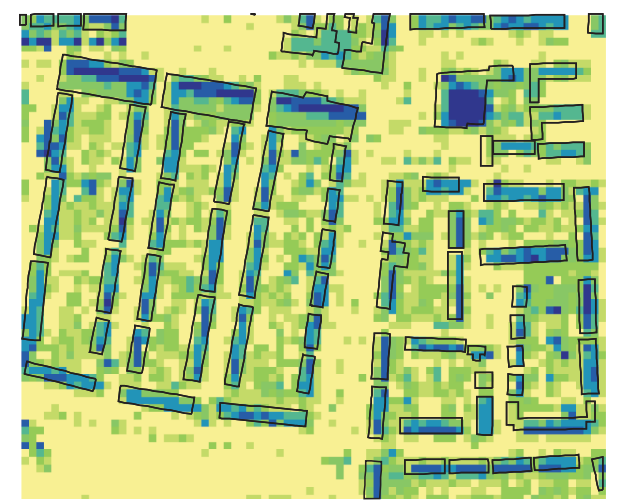

Height difference $[\mathrm{m}]$

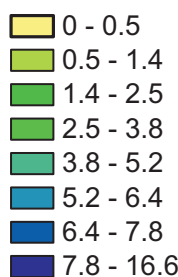

Building location

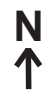

b)

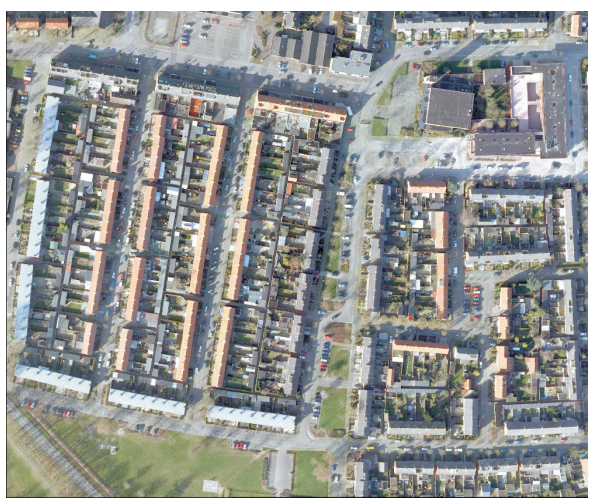

100 metres

Fig. 4. Difference map between original and filtered elevation model for urban area (a), and aerial photograph of the same area in the year 2007 (b), for location see Fig. 2.

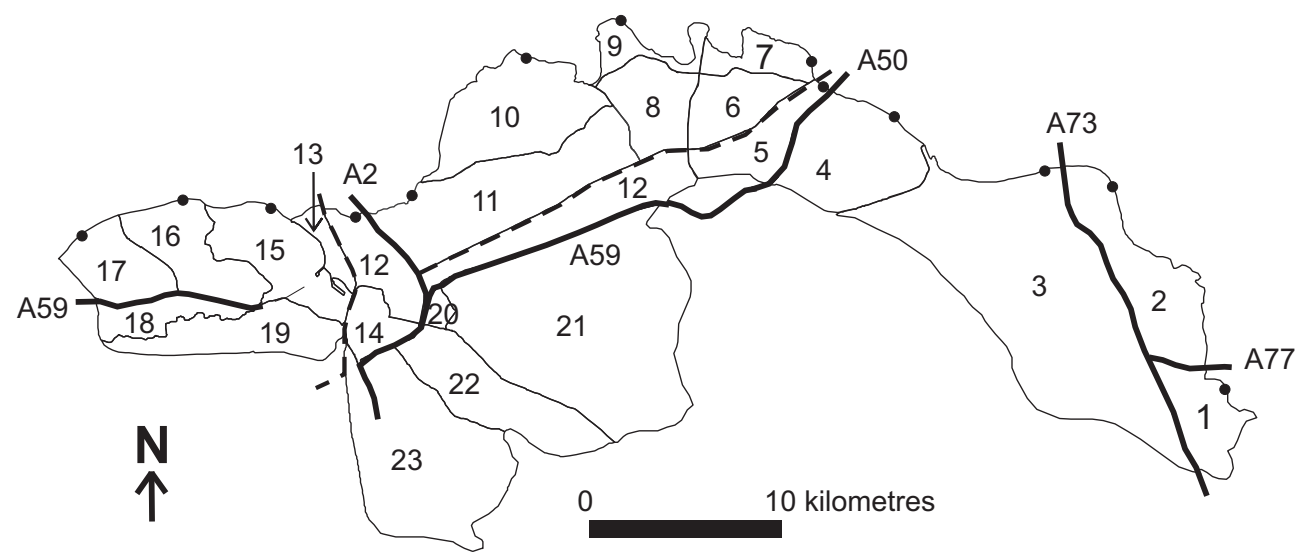

Fig. 5. Identified basins in the study area and some major highways (bold lines) and railway lines (dotted lines), the 13 breach locations are indicated by dots.

The water level for each scenario is determined by the elevation of the lowest part of the basin boundary, which was found by analysing the linear features in the original (unfiltered) elevation data. With boundary elevation, we mean the elevation of the boundary of the individual sub-basin that we derived from the elevation model. This boundary can either consist of a dike section, or a high obstacle within the area, such as elevated sediment bodies that support highways and railway lines. The reason for using this lowest elevation is because we assume that the maximum inundation height that can be reached in an area is equal to the lowest obstacle enclosing this area. As soon as the inundation level reaches this point the water will flow over into the next sub-basin. A similar approach was also taken by the Floris study, which arrived at a general estimate of flood damage by simulating the effect of maximum inundation levels for all dike ring areas in the Netherlands up to the level of the minimum dike levels around those areas (Rijkswaterstaat, 2005a). After establishing the maximum water level (relative to the national ordnance datum), inundation depths are calculated for every grid cell in the inundation scenario that has an elevation level below this water level. As the definition of the lowest part of the basin boundary undoubtedly introduces uncertainties about the maximum possible inundation depth, we also carry 
out a sensitivity analysis. The average inundation depth for each scenario is derived and subsequently reduced by $10 \%$. The effect of this reduction on the calculated damages is reported separately.

Probabilities for the inundation scenarios were taken from scenarios developed in the Floris project (Rijkswaterstaat, 2006). These probability estimates include different failure modes of the dike segments and other elements such as barrages, sluice doors, etc. Probabilities have been established from detailed research for 13 stretches of flood defences (Rijkswaterstaat, 2005c, 2006). The main and most likely failure mode for these dike segments is piping, which consists of water flowing underneath the dike body causing erosion and consequent collapse (see Vrijling, 2001). For the 42 scenarios, the breach location and the failure probability were taken from the Floris Project (Rijkswaterstaat, 2006), which established the probability of failure, which combines loading and properties of the protective structure at the locations which are the weakest points in the 13 dikes segments adjacent to the inundated area. These 13 breach locations are shown in Fig. 5. The total probability of failure in any dike segment was kept at the same level as in the Floris project (probability of $3.56 \times 10^{-2}$ per year). Note that this return period is a (very) conservative estimate (Rijkswaterstaat, 2006). It is assumed that a breach with low inundation volume is equally likely as an inundation event with a large volume of water emanating from the failure of the dike at the same location. Flooding volumes follow from the number of basins and the area that is flooded (i.e. the capacity of the area limits the volume of inflowing water). The volumes associated with the 13 scenarios from the Floris project will later in the paper be compared to the volumes from the scenarios generated in this paper. Probability $p_{i}$ of a scenario $i$ is therefore determined by

$p_{i}=\left(p_{1} / n_{1}\right)+\left(p_{2} / n_{2}\right)+\ldots\left(p_{j} / n_{j}\right)$

where $p_{1} \ldots p_{j}$ are the probabilities of failure of the different breach locations in dike segments $j$ of the basins that are inundated, and $n_{1} \ldots n_{j}$ are the number of inundation scenarios that occur due to failure of the particular dike segment. As in the Floris project, it is assumed that the dike fails in only one location, as a breach will alleviate the river water loading along the other dike segments (Rijkswaterstaat, 2006), although the exact effect of this phenomenon at present remains unknown and cannot be accurately quantified (Van Mierlo et al., 2008).

\subsection{Damage estimations}

The "Damage Scanner" model (Klijn et al., 2007) is used to calculate direct physical damages from flooding based on a series of depth-damage functions for 13 different land-use types. This Damage Scanner model is a simplification of the HIS-SSM model (Kok et al., 2005), and has been applied in the Floris project. The HIS-SSM model is the most comprehensive flood damage model available in the Netherlands, and has been described and evaluated in Messner et al. (2007). The direct damages generated by the model include damages for different loss categories, such as buildings, infrastructure, crops, and building content, as well as losses due to business interruption. The losses from business interruption consist of loss of turnover of businesses outside the flooded area, not assuming substitution effects (Kok et al., 2005). In addition to the direct damages, the HISSSM model also generates on average 5\% indirect damage for all loss categories. The estimates resulting from the Damage Scanner model that we present here therefore already include this share of indirect damage. Simplification is necessary as the large amount of detailed information required for the HIS-SSM model is not available for future land-use change projections, and exposed people and assets, which cannot be estimated for all the loss categories included in the HIS-SSM model. The damages in the Damage Scanner model are calculated on the basis of depth-damage functions, and consider inundation depth only. In the HIS-SSM model, for which the Damage Scanner model is a simplification, depth-damage functions were estimated using a combination of empirical data on flood losses and inundation depths, as well as expert judgement (Messner et al., 2007).

It should be noted that the direct damages calculated here using the Damage Scanner model comprise only a part of all tangible priced direct damages associated with flooding. Priced direct damages also include loss of vehicles, business interruption, evacuation and rescue operations, clean-up costs, and reconstruction and rehabilitation, but these are not taken into account here. In addition, there are also intangible unpriced direct damages (e.g. fatalities and injuries), as well as tangible priced (e.g. losses for companies outside the inundated area) and intangible unpriced indirect damages (e.g. societal disruption and psychological traumas) (Jonkman et al., 2008). However, direct damages generally make up a large part of the total costs, and are estimated for actual recent disastrous events to amount for between 50 and some $90 \%$ of total damage (RebelGroup, 2007). In addition, they are the most easily calculated, and are considered an important indicator of the severity of natural disasters.

Depth-damage functions relate the fraction of maximum losses to water depths (Fig. 6) and have been established for different land-use types (Klijn et al., 2007). Table 1 lists the different land-use categories and their maximum damage amounts, which represent a countrywide average and are assumed to be valid for all dike ring areas in the Netherlands. These averages hold true for dike ring 36, as a comparison between the Damage Scanner model and the detailed HISSSM model showed only a slight bias of about $0-2 \%$ (Klijn et al., 2007). 


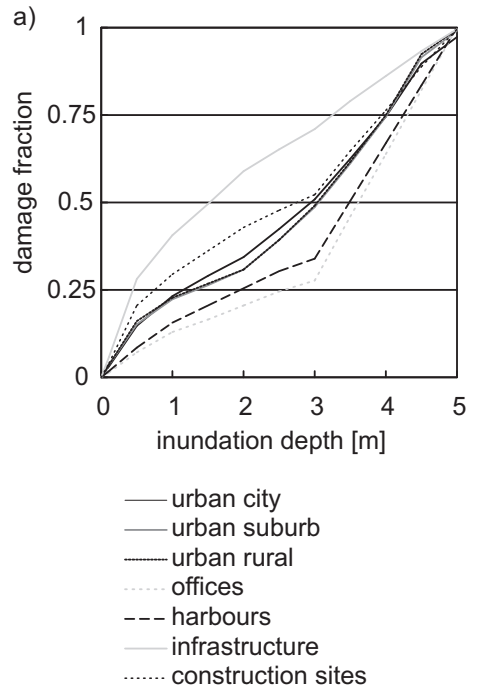

b)

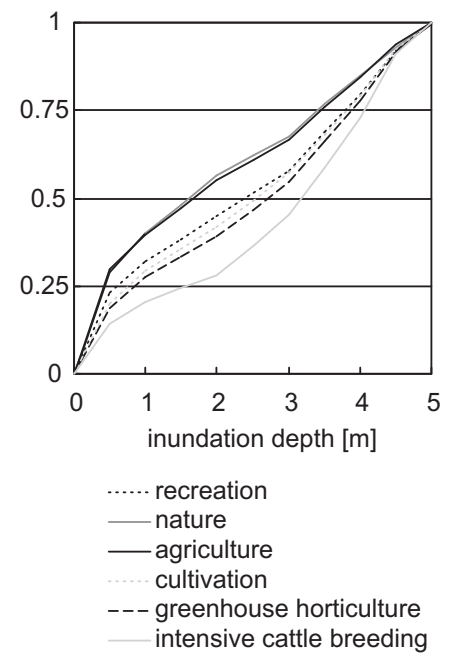

Fig. 6. Depth-damage functions for different land-use categories in the urban (a) and agricultural classes (b) (Klijn et al., 2007).

Table 1. Different land-use classes and maximum damage amounts (price level year 2000).

\begin{tabular}{|c|c|c|}
\hline ID & Land-use class & 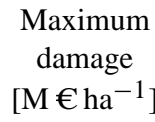 \\
\hline 0 & Urban high density & 9.1 \\
\hline 1 & Urban low density & 4.0 \\
\hline 2 & Urban rural & 3.8 \\
\hline 3 & Recreation & 0.3 \\
\hline 4 & Commercial & 6.0 \\
\hline 5 & Harbours & 5.0 \\
\hline 6 & Nature & 0.2 \\
\hline 7 & Arable land & 0.2 \\
\hline 8 & Grassland & 0.1 \\
\hline 9 & Greenhouses & 0.7 \\
\hline 10 & Livestock & 0.8 \\
\hline 11 & Infrastructure & 1.9 \\
\hline 12 & Building lot & 1.3 \\
\hline
\end{tabular}

The formula for total direct damages $D$ reads (Jonkman et al., 2008):

$D=\sum_{i}^{m} \sum_{r}^{n} \alpha_{i}\left(h_{r}\right) D_{\max , i}$

where $i$ is the land-use category, $r$ is the location in the flooded area, $m$ is the number of land-use categories, $n$ is the number of locations in the flooded area, $\alpha i\left(h_{r}\right)$ is the depth-damage function depending on inundation depth $h_{r}$, and $D_{\max , i}$ is the maximum damage amount for land-use category $i$.

\subsection{Land-use patterns}

Land-use patterns for the current situation are derived from the base map of the Land-use Scanner model (Schotten et al., 2001). This model also provides future projections of simulated land-use change for the year 2040, based on spatial claims and suitability maps for different land-use types. The impact of land-use projections under different scenarios of socioeconomic development on estimated flood damage is assessed in subsequent research (Bouwer et al., 2009). Here we apply the baseline land-use pattern from the model for the year 2000, which is also the reference year of the damage model. The land-use pattern in the case study area for this baseline situation is shown in Fig. 1. The Land-use Scanner data for the baseline situation is provided at a horizontal spatial resolution of $25 \mathrm{~m}$ and $100 \mathrm{~m}$. The $100-\mathrm{m}$ resolution is used for projections of future land-use change. In order to estimate the effect of loss calculations on a high resolution compared to a coarser resolution, we calculate losses for resolutions of 5 metre (the original DEM resolution), $25 \mathrm{~m}$, and $100 \mathrm{~m}$. For this purpose, the 25-m land-use grid has been downscaled to a 5-m resolution. It is known that the 100$\mathrm{m}$ land-use grid slightly overestimates the total area covered by residential and agricultural areas (both on average by $4 \%$ ) and considerably underestimates the total area covered by infrastructure (on average by $64 \%$ ), compared to the $25-\mathrm{m}$ grid (Loonen and Koomen, 2008). The inundation scenarios were aggregated from a 5-m grid to 25 and $100-\mathrm{m}$ grids, using the mean of the input cells.

\section{Results}

The 42 inundation scenarios consist of inundation depth maps at a horizontal resolution of 5, 25, and $100 \mathrm{~m}$. Scenarios were based on the inundation of a single basin, or 
Table 2. Inundation scenarios.

\begin{tabular}{|c|c|c|c|c|}
\hline \multirow[t]{2}{*}{ No. } & \multirow[t]{2}{*}{ Basins inundated } & \multirow{2}{*}{$\begin{array}{l}\text { Area } \\
{\left[\mathrm{km}^{2}\right]}\end{array}$} & \multirow{2}{*}{$\begin{array}{c}\text { Average } \\
\text { depth } \\
{[\mathrm{m}]}\end{array}$} & \multirow{2}{*}{$\begin{array}{l}\text { Volume } \\
{\left[10^{6} \mathrm{~m}^{3}\right]}\end{array}$} \\
\hline & & & & \\
\hline 1 & 17 & 17 & 0.64 & 11 \\
\hline 2 & 17,16 & 39 & 2.53 & 98 \\
\hline 3 & $17,16,18$ & 50 & 2.23 & 111 \\
\hline 4 & $17,16,18,15$ & 71 & 1.97 & 140 \\
\hline 5 & $17,16,18,15,19$ & 95 & 2.38 & 225 \\
\hline 6 & 16 & 22 & 2.17 & 47 \\
\hline 7 & 15,19 & 44 & 1.15 & 51 \\
\hline 8 & 16,17 & 30 & 0.60 & 18 \\
\hline 9 & 10 & 21 & 0.50 & 11 \\
\hline 10 & 10,11 & 41 & 0.42 & 17 \\
\hline 11 & $10,11,12$ & 111 & 2.03 & 225 \\
\hline 12 & 13,15 & 26 & 1.57 & 40 \\
\hline 13 & $13,12,10,11$ & 115 & 2.05 & 235 \\
\hline 14 & $13,14,15$ & 32 & 1.49 & 47 \\
\hline 15 & $14,13,10,11,12$ & 121 & 2.01 & 243 \\
\hline 16 & $15,14,13,10,11,12$ & 142 & 1.91 & 272 \\
\hline 17 & $19,15,14,13,10,11,12$ & 165 & 1.78 & 293 \\
\hline 18 & $19,16,17,15,14,13,12,11,10$ & 205 & 2.20 & 451 \\
\hline 19 & $13,15,19$ & 48 & 1.29 & 62 \\
\hline 20 & $8,9,10,11,12$ & 149 & 1.85 & 276 \\
\hline 21 & $7,6,8,11$ & 71 & 0.33 & 23 \\
\hline 22 & $7,6,8,10$ & 72 & 0.44 & 32 \\
\hline 23 & $7,6,8,9,10,11$ & 98 & 0.40 & 39 \\
\hline 24 & All basins & 374 & 1.70 & 635 \\
\hline 25 & $20,21,23,22,13,15,19,14$ & 158 & 1.07 & 169 \\
\hline 26 & $13,14,15,19$ & 72 & 1.26 & 91 \\
\hline 27 & $8,9,10,11,12,14$ & 155 & 1.82 & 282 \\
\hline 28 & $9,8,10,11$ & 61 & 0.42 & 25 \\
\hline 29 & $7,6,8,9,10,11,12,13,15,14$ & 205 & 1.80 & 369 \\
\hline 30 & $1,2,3,4,5,6,7,8,9,10,11$ & 120 & 0.52 & 62 \\
\hline 31 & $7,6,8,9,10,11,12$ & 150 & 1.75 & 263 \\
\hline 32 & $3,4,5,6,7,8,10,11$ & 103 & 0.49 & 51 \\
\hline 33 & $4,5,6,7,8$ & 57 & 0.56 & 32 \\
\hline 34 & $3,4,5,6,7$ & 49 & 0.57 & 28 \\
\hline 35 & 4 & 18 & 0.68 & 12 \\
\hline 36 & 3,4 & 23 & 0.59 & 13 \\
\hline 37 & $2,3,4$ & 29 & 0.65 & 19 \\
\hline 38 & $1,2,3,4$ & 34 & 0.64 & 22 \\
\hline 39 & 3 & 5 & 0.24 & 1 \\
\hline 40 & 2,3 & 11 & 0.58 & 7 \\
\hline 41 & $1,2,3$ & 7 & 0.59 & 4 \\
\hline 42 & 2 & 7 & 0.95 & 6 \\
\hline
\end{tabular}

a combination of several basins. A series of scenarios, developed for a single possible breach location is constructed as follows: the minimum scenario for a breach in the dike along basin 16 (Fig. 5) concerns flooding only in basin 16, this is scenario number 6 (Table 2). If the adjacent basin 17 is affected, scenario 2 occurs. More basins can be inundated (basins 15, 16, 17, 18, and 19, in scenario 5), until the railway line to the east is overflowed (Fig. 5), which gives rise to scenario 18, and so on. Table 2 lists the individual scenarios and the basins they comprise. The inundated surface areas found for the different scenarios range $5-374 \mathrm{~km}^{2}$, with an average of $81 \mathrm{~km}^{2}$. This range is comparable with the range of inundated areas, resulting from hydrodynamic modelling for this study area, that range $7-303 \mathrm{~km}^{2}$, and cover on average $98 \mathrm{~km}^{2}$ (Rijkswaterstaat, 2006).

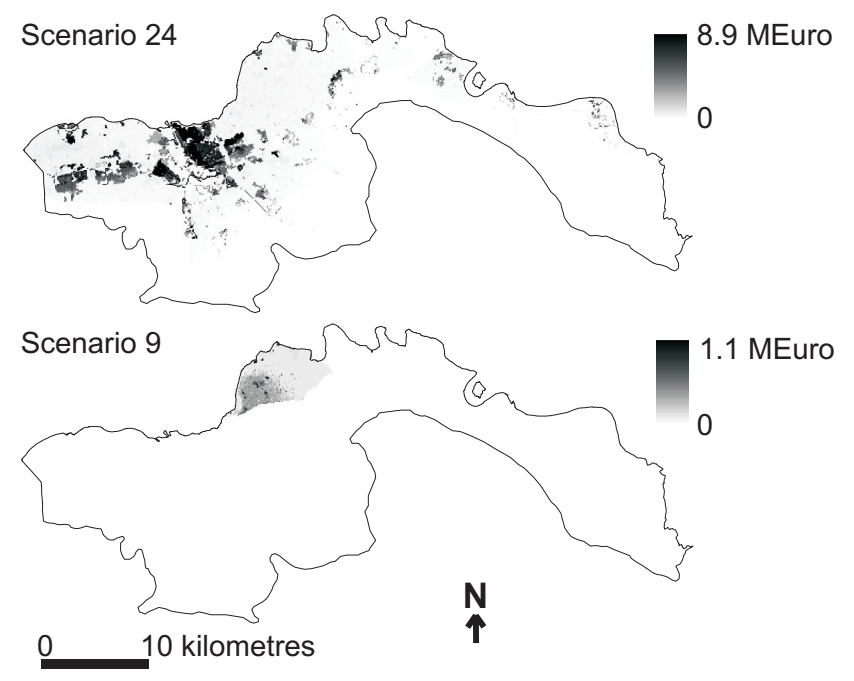

Fig. 7. Flood damage estimates for scenarios 24 and 9.

The resulting loss maps for the two inundation scenarios with the lowest and highest aggregate losses (Fig. 7) show that losses are low in the rural areas (scenarios 9 and 24), and highest in urban areas, in particular in the city of Den Bosch (scenario 24). What is clear from the map for scenario 24 , is that within the city of Den Bosch relatively low losses occur in the old city centre in the middle of the town (compare Fig. 1), due to its slightly higher elevation compared to other parts of the city. The highest losses occur in comparatively new areas with factories and business at the northeast side of the city of Den Bosch, and north of the city of Oss.

Estimated losses aggregated for all land-use types range between 49 million $€$ for scenario 9 and 11 billion $€$ for scenario 24 (Table 3 ). The Floris project reports losses between 66 million and 7.0 billion $€$ based on their 13 different inundation scenarios. Expected damages per year are calculated by aggregating the damage estimates for each scenario multiplied by the probabilities for each scenario. The average expected damage is 26.2 million $€$ per year in the current study, while the Floris project reports an expected damage of 33 million $€$ per year (Rijkswaterstaat, 2006). The main reason for this difference, apart from different loss models being used, is that our approach considers that some of the inundation scenarios cover only a relatively small geographic area and have limited inundation depths. This reduces the average loss amounts associated with the inundation scenarios.

The accurate estimate of heights of dikes and infrastructure elements affects our results, as the maximum possible depth of inundation in the individual basins is determined by these features. We believe that the most important elements, such as highways and dikes that are between $\sim 10-30 \mathrm{~m}$ wide are accurately reflected in the data. Likely, other sources of uncertainty, such as the estimated dike failure probabilities and uncertainties in the depth-damage curves will affect the 
Table 3. Scenario damages and probabilities.

\begin{tabular}{|c|c|c|c|}
\hline \multirow[t]{2}{*}{ Number } & \multicolumn{2}{|c|}{$\begin{array}{c}\text { Damage } \\
{[\mathrm{M} €]}\end{array}$} & \multirow[t]{2}{*}{ Probability } \\
\hline & $\begin{array}{l}25 \mathrm{~m} \\
\text { resolution }\end{array}$ & $\begin{array}{l}100 \mathrm{~m} \\
\text { resolution }\end{array}$ & \\
\hline 1 & 64 & 70 & $2.0 \mathrm{E}-04$ \\
\hline 2 & 901 & 939 & $3.4 \mathrm{E}-04$ \\
\hline 3 & 1488 & 1504 & $3.4 \mathrm{E}-04$ \\
\hline 4 & 2151 & 2268 & $6.1 \mathrm{E}-04$ \\
\hline 5 & 3230 & 3241 & $6.1 \mathrm{E}-04$ \\
\hline 6 & 645 & 685 & $1.4 \mathrm{E}-04$ \\
\hline 7 & 824 & 923 & $2.7 \mathrm{E}-04$ \\
\hline 8 & 119 & 163 & $2.0 \mathrm{E}-04$ \\
\hline 9 & 51 & 49 & $1.9 \mathrm{E}-04$ \\
\hline 10 & 143 & 249 & $2.0 \mathrm{E}-04$ \\
\hline 11 & 4651 & 5014 & 2.3E-04 \\
\hline 12 & 806 & 953 & $2.9 \mathrm{E}-04$ \\
\hline 13 & 4800 & 5222 & $2.3 \mathrm{E}-04$ \\
\hline 14 & 1010 & 1405 & $2.9 \mathrm{E}-04$ \\
\hline 15 & 5004 & 5657 & 2.3E-04 \\
\hline 16 & 5657 & 6366 & $5.0 \mathrm{E}-04$ \\
\hline 17 & 5817 & 6512 & $5.0 \mathrm{E}-04$ \\
\hline 18 & 7425 & 8079 & $5.0 \mathrm{E}-04$ \\
\hline 19 & 966 & 1098 & $2.2 \mathrm{E}-05$ \\
\hline 20 & 4887 & 5313 & $2.5 \mathrm{E}-04$ \\
\hline 21 & 338 & 533 & $8.9 \mathrm{E}-05$ \\
\hline 22 & 297 & 384 & $8.9 \mathrm{E}-05$ \\
\hline 23 & 417 & 615 & $8.9 \mathrm{E}-05$ \\
\hline 24 & 9663 & 10681 & $1.7 \mathrm{E}-04$ \\
\hline 25 & 2237 & 2890 & $2.2 \mathrm{E}-05$ \\
\hline 26 & 1299 & 1701 & $2.2 \mathrm{E}-05$ \\
\hline 27 & 5082 & 5749 & $2.2 \mathrm{E}-05$ \\
\hline 28 & 246 & 418 & $2.2 \mathrm{E}-05$ \\
\hline 29 & 6422 & 7103 & $1.1 \mathrm{E}-04$ \\
\hline 30 & 717 & 1053 & $1.3 \mathrm{E}-05$ \\
\hline 31 & 4793 & 5209 & 8.9E-05 \\
\hline 32 & 513 & 737 & $1.7 \mathrm{E}-04$ \\
\hline 33 & 346 & 441 & $3.1 \mathrm{E}-03$ \\
\hline 34 & 297 & 364 & $1.7 \mathrm{E}-04$ \\
\hline 35 & 128 & 150 & $2.8 \mathrm{E}-03$ \\
\hline 36 & 152 & 200 & $1.7 \mathrm{E}-04$ \\
\hline 37 & 264 & 393 & $7.2 \mathrm{E}-06$ \\
\hline 38 & 328 & 482 & $1.3 \mathrm{E}-05$ \\
\hline 39 & 23 & 51 & $1.7 \mathrm{E}-04$ \\
\hline 40 & 136 & 244 & 7.2E-06 \\
\hline 41 & 200 & 333 & $1.3 \mathrm{E}-05$ \\
\hline 42 & 112 & 193 & $7.2 \mathrm{E}-06$ \\
\hline
\end{tabular}

loss estimates more than the height of infrastructure elements and resulting inundation depths. We performed a sensitivity analysis of the effect of the estimated maximum inundation level on losses. A reduction of $10 \%$ in the inundation level of the scenarios (see Sect. 2.2), results in an average reduction of $10.9 \%$ in aggregate losses (maximum $-14.6 \%$,

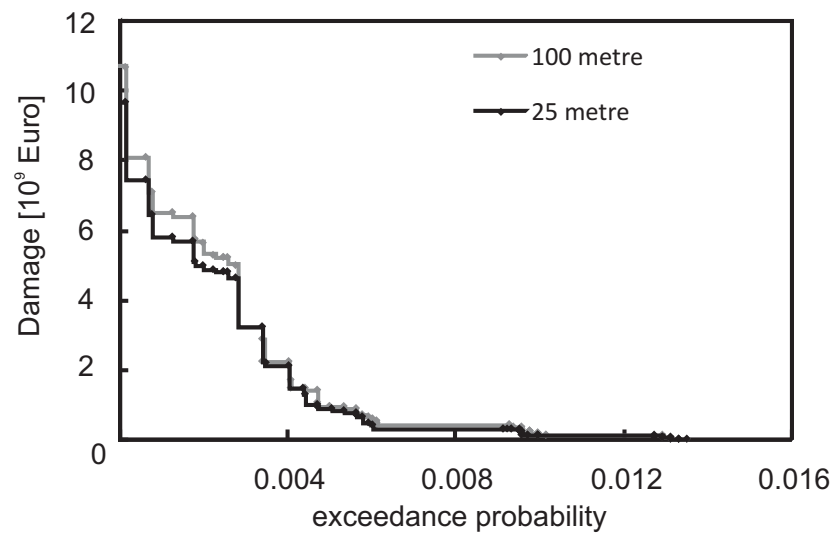

Fig. 8. Loss probability curve estimates, using the 25-m and 100-m resolution land-use maps.

minimum $-7.4 \%$ ). We believe that the actual uncertainty in the estimation of the level of the basin boundaries in our method is an order of magnitude smaller, leading to lower uncertainties in both the inundation levels and aggregate loss estimates.

Loss-probability curves are created by calculating the cumulative probability of damage events, and plotting these according to their damage size. The curves thus indicate the probability that a particular loss is equalled or exceeded. The large quantity of inundation scenarios that we created, allows the construction of a loss-probability curve, which includes relatively small events, as well as large loss events (Fig. 8). The curves for both the $25-\mathrm{m}$ and $100-\mathrm{m}$ resolution land-use maps are shown.

The loss shares for different land-use types differ considerably from those found in the Floris project for this dikering area (Table 4), but are of similar magnitude. For instance, urban areas account for the majority of losses according to our estimates (66-70\%), while Floris also reports the majority of losses in this category, albeit considerably smaller (45\%). According to our calculations, losses to agriculture and commercial land-uses come in second and third place (11 and 11-12\%, respectively), like the Floris calculations (25 and $24 \%$, respectively). The main reason for the differences is the difference in loss calculations. The Floris project uses a large series of loss-categories (Kok et al., 2005). Therefore, some differences are likely due to the differences in the loss models. The HIS-SSM loss model used in the Floris project is superior in terms of the number of loss categories, and the detail in the way losses are calculated. However, the reason for developing a simple approach lies in the application of future land-use scenarios in subsequent research, for which the simple loss model is better suited.

The extent to which the grid resolution of the loss calculations influences the damage estimates was also investigated. Losses were calculated separately for the $25-\mathrm{m}$ and 100-m inundation maps and 25-m and 100-m land-use maps. 
Table 4. Comparison of share of damage per land-use category in this study with the results from the Floris project (Rijkswaterstaat, 2006).

\begin{tabular}{lccc}
\hline $\begin{array}{l}\text { Land-use } \\
\text { category }\end{array}$ & $\begin{array}{c}\text { This study } \\
\text { [\% of total damage }] \\
25-\mathrm{m}\end{array}$ & $\begin{array}{c}\text { Floris study } \\
\text { resolution }\end{array}$ & $\begin{array}{l}\text { 100-m } \\
\text { resolution }\end{array}$ \\
\hline Agriculture & 11 & 11 & \\
Infrastructure & 8 & 4 & 6 \\
Urban & 66 & 70 & 45 \\
Commercial & 11 & 12 & 24 \\
Other & 3 & 3 & 0.2 \\
\hline
\end{tabular}

We find some differences in estimated damages between the 25-m and 100-m inundation grids. Compared to the loss estimates based on the 25-m inundation dataset, aggregate loss estimates per scenario using the 100-m dataset are up to 54\% higher for scenarios with losses less than 4 billion $€$, and up to $12 \%$ higher for scenarios with total losses of 4 billion $€$ and higher. However, overall losses are of the same order of magnitude: total expected damages amount to 23.6 million $€$ per year for the 25 -m grid, and to 26.2 million $€$ per year for the 100-m grid. More striking differences are found for the different land-use categories. Estimates for the category "infrastructure" add up to $3.9 \%$ of the total damage based on the $100-\mathrm{m}$ grid, but to $8.0 \%$ for the $25-\mathrm{m}$ grid (Table 5). As we reported earlier in Sect. 2.4 on land-use patterns, the 100-m resolution land-use grid considerably underestimates the extent of infrastructure elements (railways and roads), owing to their narrow shapes. The extent of urban areas in turn is in general overestimated using the $100-\mathrm{m}$ grid. This results in the overestimation of urban areas affected by flooding, and therefore the total loss. Expected damages in highdensity urban areas differ by as much as 1.8 million $€$ (Table 5), implying a $22 \%$ overestimation for the $100-\mathrm{m}$ grid relative to the $25-\mathrm{m}$ grid. High-density urban areas in reality account for only small extents, but are overrepresented in the $100-\mathrm{m}$ grid. These findings imply that using information with a coarse horizontal resolution can lead to considerable over and under estimates of damages for certain land-use categories. In particular, in a coarse resolution the total losses tend to be overestimated for the scenarios in which large extents of urban area are inundated.

In order to further estimate the sensitivity of the damage estimates to grid resolution, we calculated damages using the 5-m inundation grid and a re-sampled land-use map for scenario 24 , which covers all potential inundated sub-basins in the area (Fig. 7). We find that using the 5-m inundation grid, total losses equal 9246 million $€$ for scenario 24 . This is about $4.3 \%$ less than the estimate using the $25-\mathrm{m}$ inundation grid (9663 million $€$ total damage), and about
Table 5. Expected damage for different land-use categories using 25-m and 100-m resolution land-use maps.

\begin{tabular}{clcccc}
\hline ID & Land-use class & \multicolumn{2}{c}{$\begin{array}{c}\text { Expected } \\
\text { damage } \\
{\left[10^{6} € / \text { year }\right]}\end{array}$} & \multicolumn{2}{c}{$\begin{array}{c}\text { Expected } \\
\text { damage }\end{array}$} \\
& & $25 \mathrm{~m}$ & $100 \mathrm{~m}$ & $25 \mathrm{~m}$ & $100 \mathrm{~m}$ \\
\hline 0 & Urban high density & 8.1 & 9.9 & 34.4 & 37.7 \\
1 & Urban low density & 7.0 & 7.9 & 29.6 & 30.1 \\
2 & Urban rural & 0.6 & 0.6 & 2.5 & 2.4 \\
3 & Recreation & 0.0 & 0.1 & 0.2 & 0.2 \\
4 & Commercial & 2.6 & 3.2 & 11.2 & 12.1 \\
6 & Nature & 0.2 & 0.3 & 0.9 & 1.0 \\
7 & Arable land & 0.7 & 0.8 & 3.1 & 2.9 \\
8 & Grassland & 1.7 & 1.9 & 7.4 & 7.2 \\
9 & Greenhouses & 0.1 & 0.1 & 0.4 & 0.3 \\
10 & Livestock & 0.1 & 0.1 & 0.4 & 0.3 \\
11 & Infrastructure & 1.9 & 1.0 & 8.0 & 3.9 \\
12 & Building lot & 0.5 & 0.5 & 2.0 & 1.9 \\
& Sum & 23.6 & 26.2 & 100 & 100 \\
\hline
\end{tabular}

$13 \%$ less than the estimate using the 100-m inundation grid (10 681 million $€$ total damage). This implies that using even higher resolution inundation maps, loss estimates in general will decline, and the estimates for some land-use categories such as infrastructure may increase.

\section{Discussion and conclusions}

The aim of this study was to develop a method that is able to simulate inundation in polder areas, and calculate associated flood losses. In particular, the method could be used for detailed scenario studies of the impact of future socioeconomic and climatic developments on flood risks. The relatively small number of scenarios that can be reasonably produced by hydrodynamical modelling, and their relatively coarse horizontal resolution, limit the usefulness of these models for high spatial resolution loss estimates for large areas. The method compliments more detailed hydrodynamic approaches, by providing a risk assessment with sufficient accuracy, but at a larger geographic scale. This paper has demonstrated that the present approach allows simulation of flood events for a number of dike breach locations, based on a high-resolution elevation model. A wide range of variations in the volume of inundating water is taken into account. In addition, the uncertainty related to different amounts of inundating water volumes and the potential collapse of linear obstacles can be taken into account, as the scenarios include versions with and without inundation of adjacent basins that are protected by linear landscape elements. 
The method was applied to a polder area in the south of the Netherlands, at risk from flooding of the river Meuse. The effort for developing the current range of scenarios is considerably less than the effort involved in hydrodynamic modelling. Our scenarios and consequent flood losses were constructed to illustrate the potential range of flood losses, and to assess the relative impact of land-use and socioeconomic changes in subsequent research. The generation of a large variety of inundation scenarios provides a good basis for constructing loss probability curves. Such curves are important in risk analysis as well as in the development and evaluation of flood management policies. These curves allow an estimate of the maximum losses, as well as the expected annual average losses. The calculated range and expected values of damages compare reasonably well with earlier calculations from the Floris study (Rijkswaterstaat, 2006), which estimated flood losses on the basis of hydrodynamic flood simulations and a more detailed loss model. Yet, there are some important differences between the losses estimated in our study and those found in the Floris study, that mainly result from the different loss modelling approaches.

We also showed that the resolution of loss modelling has a considerable influence on losses calculated with the same loss model. Our study showed that damage estimates based on coarse inundation maps, errors can amount to $22 \%$ overestimates and $100 \%$ underestimates for the categories of high density urban areas and infrastructure, respectively. This has important implications for the proper evaluation of flood risks using coarse resolution inundation scenarios that are applied in flood risk modelling. Losses from urban areas and infrastructure are important, because they comprise the largest share in the total aggregate losses. The estimation of the effectiveness of mitigation measures in the urban environment and infrastructure needs to take account of the actual risks. The damages estimated using the high resolution inundation grids are expected to be closer to the actual potential losses, as inundation depths are more accurately estimated, and their position is more accurate compared to the land-use classes. We estimate the maximum damage to be 9.2 billion $€$ using the high resolution (5-m), while the Floris project estimates the maximum damage at 7.5 billion $€$ (Rijkswaterstaat, 2006) using a more detailed loss model. Other studies have estimated these maximum losses for this dike ring to be 17.7 billion $€$ (Rijkswaterstaat, 2005a) and 10.3 billion $€$ (Klijn et al., 2007).

It is important to stress that major uncertainties also occur in the loss modelling part, and not just in the inundation depth assessment. In particular, the relation between inundation depth and damage fraction is generally quite uncertain. The actual form of the depth-damage curves is unknown, and is a major source of uncertainty in flood risk estimates (Merz et al., 2004, 2008). Also the maximum damage amounts used here (Table 1) are just estimates for average asset values for the entire country, and not the actual objects values in the case study area.
Acknowledgements. We thank Karin de Bruijn (Deltares) for her help in applying the Damagescanner model that she developed, and for her comments on this paper. Rijkswaterstaat (Dutch Ministry of Transport, Public Works and Water Management) kindly provided the AHN elevation data, and the ground level observation point data. Slagboom en Peeters Luchtfotografie BV, Teuge, The Netherlands, provided the aerial imagery used in Figs. 2 and 4. The comments and suggestions from Dapeng $\mathrm{Yu}$ and an anonymous referee greatly helped to improve this paper. Finally, we thank our colleagues Hans de Moel, Oleg Sheremet, and Wouter Botzen for their comments. This research is part of the project "Financial arrangements for disaster losses under climate change", supported by the Dutch National Research Programme "Climate changes Spatial Planning" (http://www.climatechangesspatialplanning.nl). All errors and opinions remain ours.

Edited by: A. Barros

Reviewed by: D. Yu and another anonymous referee

\section{References}

Aerts, J., Sprong, T., and Bannink, B. A. (Eds.): Aandacht voor Veiligheid, DG Water report 009/2008, 2008 (in Dutch).

Apel, H., Aronica, G. T., Kreibich, H., and Thieken, A. H.: Flood risk analyses-how detailed do we need to be?, Nat. Hazards, 49, 79-98, 2009.

Botzen, W. J. W. and Van den Bergh, J. C. J. M.: Insurance against climate change and flooding in the Netherlands: present, future, and comparison with other countries, Risk Anal., 28, 413-426, 2008.

Bouwer, L. M. and Vellinga, P.: On the flood risk in the Netherlands, in: Flood Risk Management in Europe: Innovation in Policy and Practice, edited by: Begum, S., Stive, M. J. F., and Hall, J. W., Springer, Berlin, 469-484, 2007.

Bouwer, L. M., Bubeck, P., and Aerts, J. C. J. H.: Increases in future flood risk due to climate and development in a Dutch polder area, Global Environmental Change, submitted, 2009.

CBS: Statistiek van het bodemgebruik 2000, Centraal Bureau voor de Statistiek, Voorburg/Heerlen, 2000.

De Bruijn, K. M. and Klijn, F.: Risky places in the Netherlands: a first approximation for floods, Journal of Flood Risk Management, 2(1), 58-67, 2009.

ESRI, Catchment Grid Delineation function, ArcGIS Hydro tools, Environmental Systems Research Institute website, available at: http://support.esri.com/index.cfm?fa=downloads. dataModels.filteredGateway $\backslash \&$ dmid=15, last access: 27 October 2009.

Gerritsen, H.: What happened in 1953? The Big Flood in the Netherlands in retrospect, Philos. T. R. Soc. A, 363, 1271-1291, 2005.

Huising, E. and Pereira, G.: Errors and accuracy estimates of laser data acquired by various laser scanning systems for topographic applications, ISPRS J. Photogramm., 53, 245-261, 1998.

Hunter, N. M., Bates, P. D., Horrit, M. S., and Wilson, M. D.: Simple spatially-distributed models for predicting flood inundation: a review, Geomorphology, 90, 208-225, 2007.

Jonkman, S. N., Bočkarjova, M., Kok, M., and Bernardini, P.: Integrated hydrodynamic and economic modelling of flood damage in the Netherlands, Ecol. Econ., 66, 77-90, 2008. 
Klijn, F., Baan, P., De Bruijn, K. M., and Kwadijk, J.: Overstromingsrisico's in Nederland in een veranderend klimaat: verwachtingen, schattingen en berekeningen voor het project Nederland Later, WL Delft Hydraulics report Q4290.00, 2007 (in Dutch).

Kok, M., Huizinga, H. J., Vrouwenvelder, A. C. W. M., and Van den Braak, W. E. W.: Standaardmethode 2005, Report PR999.10, HKV consultants and TNO Bouw, Lelystad, 2005.

Kreibich, H., Piroth, K., Seifert, I., Maiwald, H., Kunert, U., Schwarz, J., Merz, B., and Thieken, A. H.: Is flow velocity a significant parameter in flood damage modelling?, Nat. Hazards Earth Syst. Sci., 9, 1679-1692, 2009, http://www.nat-hazards-earth-syst-sci.net/9/1679/2009/.

Loonen, W. and Koomen, E.: Calibration and validation of the Land Use Scanner allocation algorithms, Report 550026002/2008, Netherlands Environmental Assessment Agency, Bilthoven, 2008.

Merz, B., Kreibich, H., Thieken, A., and Schmidtke, R.: Estimation uncertainty of direct monetary flood damage to buildings, Nat. Hazards Earth Syst. Sci., 4, 153-163, 2004,

http://www.nat-hazards-earth-syst-sci.net/4/153/2004/.

Merz, B., Kreibich, H., and Apel, H.: Flood risk analysis: uncertainties and validation, Östereichische Wasserwirtschaft, 05-06, 1-6, 2008.

Messner, F., Penning-Rowsell, E., Green, C., Meyer, V., Tunstall, S., and Van der Veen, A.: Evaluating flood damages: guidance and recommendations on principles and methods, Floodsite report T09-06-01, 2007.

MNP: Dutch dikes and risk hikes: a thematic policy evaluation of risks of flooding in the Netherlands, Report 500799002, Milieuen Natuurplanbureau, Bilthoven, 2004 (in Dutch).

NRC: Elevation Data for Floodplain Mapping, National Research Council, Washington, DC, 2007.

RebelGroup: Indirecte effecten overstromingen in het kader van HIS-SSM en de KBA WV21, Discussion paper, RebelGroup Advisory Belgium, Antwerp, 2007 (in Dutch).

Rijkswaterstaat: Veiligheid Nederland in Kaart: Globale Schadeberekening, Rijkswaterstaat, Dienst Weg- en Waterbouwkunde, Delft, 2005a (in Dutch).
Rijkswaterstaat: Flood risks and safety in the Netherlands (Floris), Report DWW-2006-014, Rijkswaterstaat, Dienst Weg- en Waterbouwkunde, Delft, 2005b.

Rijkswaterstaat: Veiligheid Nederland in Kaart: Overstromingsrisico dijkring 36 Land van Heusden/De Maaskant en 36a Keent, Rijkswaterstaat, Dienst Weg- en Waterbouwkunde, Delft, 2005c (in Dutch).

Rijkswaterstaat: Veiligheid Nederland in Kaart: Risicocase dijkring 36 Land van Heusden/De Maaskant, berekening van het overstromingsrisico, Report DWW-2006-011, Rijkswaterstaat, Dienst Weg- en Waterbouwkunde, Delft, 2006 (in Dutch).

Schotten, K., Goetgeluk, R., Hilferink, M., Rietveld, P., and Scholten, H.: Residential construction, land use and the environment simulations for the Netherlands using a GIS-based land use model, Environ. Model. Assess., 6, 133-143, 2001.

Smith, K. and Ward, R.: Floods: Physical Processes and Human Impacts, John Wiley and Sons, New York, 1998.

Van Dantzig, D.: Economic decision problems for flood prevention, Econometrica, 24, 276-287, 1956.

Van der Most, H. and Wehrung, M.: Dealing with uncertainty in flood risk assessment of dike rings in the Netherlands, Nat. Hazards, 36, 191-206, 2005.

Van Mierlo, M. C. L. M., Schweckendiek, T., and Courage, W. M. G.: Importance of river system behaviour in assessing flood risk, in: Floodrisk 2008, The European Conference on Flood Risk Management: Research into Practice, Oxford, UK, 30 September-2 October, 2008.

Vrijling, J. K.: Probabilistic design of water defense systems in the Netherlands, Reliab. Eng. Syst. Safe., 74, 337-344, 2001.

Vrijling, J. K., Van Hengel, W., and Houben, R. J.: Acceptable risk as a basis for design, Reliab. Eng. Syst. Safe., 59, 141-150, 1998.

Wind, H. G., Nierop, T. M., De Blois, C. J., and De Kok, J. L.: Analysis of flood damages from the 1993 and 1995 Meuse floods, Water Resour. Res., 35, 3459-3466, 1999. 